\title{
Approaches to combatting illegal, unreported and unregulated fishing
}

\author{
Poor ocean governance enables illegal, unreported and unregulated (IUU) fishing with negative impacts on seafood \\ value chains, environment, society and global food security. A new Blue Paper outlines strategies - based on \\ transparency and international cooperation - that could turn the tide on IUU fishing practices.
}

Tony Long, Sjarief Widjaja, Hassan Wirajuda and Stephanie Juwana

T arget 14.4 of the United Nations (UN) Sustainable Development Goals - to end overfishing and illegal, unreported and unregulated (IUU) fishing - is off-track but could be met by the end of 2020 should strategies that reward transparency and increase international cooperation be promoted moving forward. One-fifth of all wild-caught fish is likely to be illegal or unreported, which equated to US\$10-23.5 billion in industry losses in 2009'. The Pacific Island region represents US\$616 million annually, with 276,000-338,000 tonnes of Pacific tuna illegally caught each year ${ }^{2}$. Losses induced by IUU fishing increase when impacts across the seafood value chain are considered $^{3}-$ the economic value never reaches the communities that are the rightful beneficiaries. Illegal fishing has substantial social and environmental costs. Destruction of habitats and overfishing of mature fish compromise the future health of ecosystems and the value of fisheries, upset marine food webs and threaten species with extinction. Coastal communities face food security risks and potential disruption to social cohesion $^{4}$. The UK Ministry of Defence's Global Strategic Trends $2018^{5}$ highlights that international conflict over falling fish stocks is a potential scenario. IUU fishing is frequently connected to transnational organized crime, human rights abuses, tax evasion, piracy, and drugs, arms and human trafficking ${ }^{6-9}$.

Total global consumption of seafood is projected to increase by 30 million metric tonnes, up more than $20 \%$, by 2030 , with the highest demand in Latin America, Africa, Oceania and Asia ${ }^{10}$. Fish act as an important source of essential nutrients, including omega-3 fatty acids, iodine, vitamin $\mathrm{D}$ and calcium, which are important during pregnancy and the first two years of a child's life ${ }^{10}$. To meet the growing demand for fish, governing bodies must manage fish stocks and other marine resources in a sustainable, joined up and equitable way.
This approach would strengthen resilience and potentially increase profits in some regions ${ }^{11}$. With judicious conservation and improved management, capture fisheries could produce up to $20 \%$ more catch and up to $40 \%$ more than projected future catch under current fishing pressures ${ }^{12}$. However, IUU fishing undermines this progress - it skews data on assessments of fish stocks and risks the collapse of overfished populations.

\section{Modus operandi of IUU fishing}

Perpetrators of IUU fishing tend to follow particular methods that reduce financial costs and regulatory burdens or confound attempts to track the history of the vessel. These methods are currently high gain and low risk.

Utilizing transshipment. Catch monitoring at sea is patchy and implementation varies greatly, allowing IUU fishing vessels to 'launder' fish at sea by transferring their catch to another vessel and continue fishing without having to enter port. In the western and central Pacific Ocean alone, it is estimated that more than US $\$ 142$ million worth of tuna and tuna-like products is lost in illegal transshipments each year².

\section{Operating under flags of convenience. A vessel flying a 'flag of convenience' is registered to a state with no genuine link to its owners or operators. This can offer advantages such as limited regulatory oversight, ease of registration, reduced taxation and obscuring beneficial ownership. IUU fishing vessel owners may use them to circumvent management and conservation measures, avoid penalties for illegal fishing, or re-flag and change names to confuse management and surveillance authorities, known as 'flag hopping' ${ }^{13}$.}

Landing catch in ports of convenience. IUU fishing vessels frequent ports where they can avoid proper inspection due to a lack of capacity, poor recording systems or corruption among inspectors. These ports of convenience allow the illegal fishing industry to access the marketplace and logistical support for their vessels at low risk of detection. Some free trade ports (or free economic zones) with favourable customs regulations and few or no controls on landings or transshipment can be classified as ports of convenience.

Creating complex ownership networks. Fisheries and their value chains operate across jurisdictions, creating convoluted ownership networks where the true beneficial owner is difficult to discern. Investigating and prosecuting illegal fishing under this construct is complex and requires close cooperation and information sharing among countries, agencies and international institutions, which is often lacking. This means illegal fishing cases at the national level focus on prosecuting only the vessel and its crew for a specific violation, with little effort to identify possible illegal activities by the same vessel in other jurisdictions, or prosecute the networks and individuals behind IUU fishing operations.

Deactivating vessel identification and monitoring systems. Many states require fishing boats operating in their waters to send information on their position and activities via a vessel monitoring system, while larger vessels are required to broadcast their position via the satellite-based automatic identification system. IUU fishing vessels can deactivate or manipulate these systems to hide their identity and location.

Producing fraudulent documents and vessel identification. Much of fisheries management is paper based - even where e-documentation is present it is rarely used across the whole supply chain. Illegal operators forge or alter vessel registration certificates, fishing licences, catch certificates or other documents to hide illegal activities (including past 
irregularities), avoid regulations, costs and other obligations, or gain access to additional resources, services or benefits.

Exploiting poor working conditions and safety standards. IUU fishing vessels are less likely to provide their crews with adequate labour conditions, training or safety equipment, and are more likely to fish in hazardous weather, allowing them to minimize upfront costs. Some migrant workers seeking employment overseas have been tricked with false promises of jobs on land, but end up toiling in abhorrent working conditions on board unsafe fishing vessels roaming the high seas ${ }^{14}$.

\section{Addressing ocean governance}

IUU fishing is a result of poor governance - particularly on the high seas outside national jurisdiction - where governance frameworks are weak, fragmented, and poorly implemented or enforced ${ }^{15}$. The Food and Agriculture Organization's (FAO) International Plan of Action to Prevent, Deter and Eliminate Illegal, Unreported and Unregulated Fishing (IPOA-IUU) remains relevant, despite being nearly 20 years old ${ }^{16}$. Many countries have used this voluntary guidance to develop their own national plans of action ${ }^{17}$, but updates are required to reflect developments in technological tools and transparency, and include measures to support national implementation.

Recent developments indicate growing political will to address IUU fishing. A 2018 UN resolution on sustainable fisheries highlights IUU fishing and the importance of policies to combat it; a new legally binding instrument to protect marine biodiversity in areas beyond national jurisdiction is being considered under the UN Convention on the Law of the Sea (UNCLOS). Declarations on combating IUU fishing were issued at the G7 (Charlevoix Blueprint 2018) and the G20 (Osaka Leaders Declaration 2019), while an Asia-Pacific Economic Cooperation roadmap to combat IUU fishing was launched in 2018.

The FAO Port States Measures Agreement (PSMA), which came into force in $2016^{18}$ is the first binding international agreement dealing specifically with IUU fishing. It requires parties to place tighter controls on foreign-flagged vessels seeking to use their ports. States can choose to inspect or simply refuse entry or access to ports to known or, importantly, suspected IUU fishing or support vessels. Widespread implementation of the PSMA will be a cost-effective and efficient way to stop IUU caught fish entering the market.

The International Labour Organization (ILO) Work in Fishing Convention
(C188) and the International Maritime Organization (IMO) Cape Town Agreement (CTA) are two policies that countries should implement or accede to. When the CTA becomes operational, it will set minimum safety requirements for fishing vessels 24 metres or longer that operate on the high seas and will empower port states to carry out safety inspections that can help ensure transparency of fishing and crew activities. Implementing and enforcing labour standards will likely reduce the profit margins of IUU fishers - and act as an indirect deterrent to IUU fishing.

These measures will address failures of ocean governance that have hampered progress in tackling IUU fishing over many years. In tandem, new credible and affordable technologies are emerging that can improve monitoring of fishing fleet activity. Machine learning powers algorithms that can detect fishing activity, transshipments at sea and vessels entering restricted areas or even turning off their signals ${ }^{19}$. Electronic monitoring of activity on board vessels can help spot excessive bycatch or potential illegal catch of species such as sharks ${ }^{20,21}$. The increasing use of e-documentation can reduce manipulation of catch figures, while blockchain technology promises full traceability of fish products from their origin to the end user ${ }^{22}$.

\section{Blue Paper proposals for combatting IUU fishing}

The High Level Panel for a Sustainable Ocean Economy Blue Paper on IUU fishing and its associated drivers ${ }^{17}$ sets out more than 70 actions that international bodies, nation states, industry, scientists and civil society need to take to effectively combat IUU fishing and its key drivers - economic incentives, weak governance and barriers to enforcement.

\section{Enhanced regional cooperation. A} joined-up approach across governments, civil society, science, industry and the private sector is urgently needed. Regional fisheries management organizations (RFMOs), as a key part of fisheries governance and regional cooperation, must function consistently across different regions. Areas for action include addressing non-uniformity of RFMO regulations, improving coordination and data transparency, and applying strong sanctions against flag states that fail to enforce regulations or take action in cases of presumed IUU fishing by their vessels. Digitally documenting catch data will promote global exchange of information all states should adopt secure digital tools to store information on vessel registration, licences, unloading records, catch location and information, and crew documentation.

Tighter controls at ports. States should ratify and implement the PSMA as a cost-effective method of preventing IUU catch from entering the market ${ }^{17}$ and encouraging data sharing to facilitate enforcement. Poor implementation of the CTA and ILO C188 noticed during inspections under the PSMA could be flagged to the states' maritime and labour agencies. Industry and the private sector must require compliance with such regulations as part of their conditions of contract or trade.

Global transparency in fisheries. Demanding transparency - in ownership, fishing authorizations, transshipment and vessel tracking - makes it far more difficult to bring IUU fish to port. It shifts the burden to the fisher to prove compliance, rather than the state to prove malpractice, and makes monitoring and inspections easier to prioritize and more cost-effective. Easy access to port and swift landing of catch create economic incentives for transparency, while technological advances are making it simpler to track the movements of both fishing vessels and fish catch through the value chain. Missing data raises suspicions and leads to delays in landing catch and inspection or, under the PSMA, even being denied entry to port. Business, industry and finance institutions can drive change by requiring transparency and traceability in contracts.

IUU fishing threatens food security and livelihoods; bonded labour and transnational crime result in detrimental impacts on the economy, society and the environment. Nevertheless, it persists because ocean governance is disconnected and inconsistently applied. By promoting transparency, information sharing and global cooperation, the Blue Paper offers a cost-efficient and effective means to stamp out the huge damage IUU fishing does to fisheries - and all who depend on them.

Tony Long ${ }^{1 凶}$, Sjarief Widjaja², Hassan Wirajuda ${ }^{3}$ and Stephanie Juwana ${ }^{4}$ ${ }^{1}$ Global Fishing Watch, Washington, DC, USA. ${ }^{2}$ Ministry of Marine Affairs and Fisheries of the Republic of Indonesia, Jakarta, Indonesia. ${ }^{3}$ Ministry of Foreign Affairs of the Republic of Indonesia, Jakarta, Indonesia. ${ }^{4}$ Indonesia Ocean Justice Initiative, Jakarta, Indonesia.

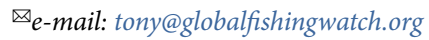

Published online: 16 July 2020

https://doi.org/10.1038/s43016-020-0121-y 
References

1. Agnew, D. J. et al. PLoS ONE 4, e4570 (2009).

2. Towards the Quantification of Illegal, Unreported and Unregulated (IUU) Fishing in the Pacific Islands Region https://go.nature. com/2VJDuiP (MRAG Asia Pacific, 2016).

3. Konar, M. et al. The Scale of Illicit Trade in Pacific Ocean Marine Resources Working Paper (World Resources Institute, 2019).

4. Tinch, R. et al. Costs of Illegal, Unreported and Unregulated (IUU) Fishing in EU Fisheries (Economics for the Environment Consultancy, 2008).

5. Development, Concepts and Doctrine Centre Global Strategic Trends https://go.nature.com/3f7vL5M (UK Ministry of Defence, 2018).

6. Sumaila, U. R. \& Bawumia, M. Fish. Res. 157, 154-163 (2014)

7. Haenlein, C. Below the Surface: How Illegal, Unreported and Unregulated Fishing Threatens Our Security (Royal United Services Institute for Defence and Security Studies, 2017).

8. Implementation of the International Plan of Action to Deter, Prevent and Eliminate Illegal, Unreported and Unregulated Fishing (Food and Agriculture Organization of the United Nations, 2002).
9. Sumaila, U. R. Ghanaian J. Econ. 6, 108-116 (2018).

10. The State of World Fisheries and Aquaculture 2018: Meeting the Sustainable Development Goals (Food and Agriculture Organization of the United Nations, 2018).

11. Gaines, S. et al. The Expected Impacts of Climate Change on the Ocean Economy https://go.nature.com/3gcZCK9 (World Resources Institute, 2019).

12. Costello, C., Cao, L. \& Gelcich S. The Future of Food from the Sea https://go.nature.com/38hqd5V (World Resources Institute, 2019).

13. Lowering the Flag: Ending the Use of Flags of Convenience by Pirate Fishing Vessels (Environmental Justice Foundation, 2009).

14. The Cape Town Agreement Explained: How One International Treaty Could Combat Illegal Fishing and Save Lives https://go.nature.com/2YIHfqE (Pew Charitable Trusts, 2018).

15. From Decline to Recovery: A Rescue Package for the Global Ocean (Global Ocean Commission, 2014).
16. International Plan of Action to Prevent, Deter and Eliminate Illegal, Unreported and Unregulated Fishing (Food and Agriculture Organization, 2001).

17. Widjaja, S., Long, T. \& Wirajuda, H. Illegal, Unreported and Unregulated Fishing and Associated Drivers https:// go.nature.com/2ByR29Z (World Resources Institute, 2019).

18. Agreement on Port State Measures to Prevent, Deter and Eliminate Illegal, Unreported and Unregulated Fishing (Food and Agriculture Organization of the United Nations, 2009).

19. Ford, J. H. et al. PLoS ONE 13, e0201640 (2018).

20. van Helmond, A. T. M. et al. Fish Fish. 21, 162-189 (2020).

21. Plet-Hansen, K. S., Bergsson, H. \& Ulrich, C. Fish. Res. 215, 114-122 (2019).

22. Probst, W. N. ICES J. Mar. Sci. https://doi.org/10.1093/icesjms/ fsz036 (2019).

Competing interests

The authors declare no competing interests. 